\title{
Implementation of the Tahfidz Quran Program in Developing Islamic Character
}

\author{
Najiburrahman $^{1 凶}$, Yunita Noor Azizah², Jazilurrahman³, Wafiq Azizah ${ }^{3}$, Nur Aisyatul \\ Jannah $^{3}$ \\ Ilmu Qur'an dan Tafsir, Universitas Nurul Jadid, Paiton, Probolinggo, Indonesia(1); \\ Pendidikan Agama Islam, Universitas Islam Negeri Sultan Aji Muhammad Idris, Samarinda, \\ Indonesia(2); Pendidikan Agama Islam, Universitas Nurul Jadid, Paiton, Probolinggo, \\ Indonesia(3); Pendidikan Islam Anak Usia Dini, Universitas Nurul Jadid, Paiton, Probolinggo, \\ Indonesia ${ }^{(3)}$ \\ DOI: $\underline{10.31004 / o b s e s i . v 6 i 4.2077}$
}

\begin{abstract}
The purpose of the study was to examine the implementation of the Tahfidz Qur'an program in developing Islamic character in Masyithoh Sukodadi Kindergarten (TK) Paiton Probolinggo. This type of research is qualitative with a phenomenological approach. The research subjects were teachers, principals and students at Masyithoh Kindergarten. Methods of data collection using interviews, observation and documentation. Data analysis uses the Constant Comparative Analysis model with three processes, namely open coding, axial coding and selective coding. The results of the field research obtained findings of the implementation of the Tahfidz Qur'an program in developing Islamic character in Masyithoh Kindergarten (TK) namely the preparation, planning, and implementation of the program. While the implications of the Qur'an tahfidz program in developing Islamic character in Masyithoh Kindergarten through the achievement of forming 4 characters, namely: religious, disciplined, patient and istiqomah
\end{abstract}

Keywords: tahfidz quran, islamic character; eraly childhood

\begin{abstract}
Abstrak
Tujuan penelitian adalah mengkaji implementasi program Tahfidz Qur'an dalam mengembangkan karakter islami di Taman Kanak-Kanak (TK) Masyithoh Sukodadi Paiton Probolinggo. Jenis penelitian ialah kualitatif dengan Pendekatan fenomenologi. Subjek penelitian ialah guru, kepala sekolah dan peserta didik di TK Masyithoh. Metode pengumpulan data menggunakan wawancara, observasi dan dokumentasi. Analisis data mengunkan model Constant Comparative Analysis dengan tiga proses yaitu pengkodean terbuka, pengkodean aksial dan pengkodean selektif. Hasil penelitian lapangan diperoleh temuan implementasi program Tahfidz Qur'an dalam mengembangkan karakter islami di Taman Kanak-Kanak (TK) Masyithoh yaitu persiapan, perencanaan, dan pelaksanaan program. Sedangkan implikasi program tahfidz Qur'an dalam mengembangkan karakter islami di TK Masyithoh melalui pencapaian membentuk 4 karakter yaitu : religius, disiplin, sabar dan istiqomah.
\end{abstract}

Kata kunci: tahfidz quran; karakter islami; anak usia dini

Copyright (c) 2022 Najiburrahman, et al.

$\triangle$ Corresponding author:

Email Address : najiburrahman@unuja.ac.id (Probolinggo, Indonesia)

Received 15 November 2021, Accepted 5 February 2022, Published 1 March 2022 


\section{INTRODUCTION}

Globalization and modernization have a very fundamental and significant impact (Dakir et al., 2021). So that the opening of opportunities and opportunities both in the fields of education, economy, social and culture has brought people to an instant life with the ease of available facilities (Hamid Wahid et al., 2021). This convenience can also be felt in the field of technology. The impact of advanced technology can provide comfort in various activities, information facilities such as television are available in almost every home. Multiple channels and shows can be freely chosen anytime and anywhere (Baharun, Muali, et al., 2021). Moreover, with the availability of the internet, which offers a variety of information and services that are easy and fun (Mustajab et al., 2020). Because of its convenience, one does not need to leave the house to get information.

The various kinds of shows currently shown on television contain little educational value. Like a television program; Films, soap operas, advertisements, and talk shows do not contribute to the importance of education for children. Even children's cartoon films have little educational value and character and cannot be separated from violent behaviour (Baharun \& Badriyah, 2021). The presented news also displays criminal information, which is quite horrific. Films and soap operas that are screened contain pornography and pornographic actions that are inappropriate for children and adults to watch. The storyline of films and soap operas depicts hedonic and wasteful behavior far from Indonesian culture (Hermawan, 2020). This indirectly hurts the character of the Indonesian people, especially children, because they will automatically imitate and follow behavior that is not by the nature of the Indonesian nation. In addition, the activities and busyness of parents, especially in big cities, have diverted the attention and parenting patterns of parents towards their children. Lack of parental attention and little time with children leads to changes in children's attitudes and behavior. This results in the child engaging in unwanted behaviour (Jannah, 2021).

According to data from the Indonesian Child Protection Commission (KPAI), there were 229 cases of student brawls from January to October 2013; this number increased by $44 \%$ from 2012, and 19 students died (Arliman S, 2018). Seeing this sad reality, the Chairperson of the Indonesian Child Protection Commission (KPAI) said that 2014 was an emergency year against child violence3. On the official website, KPAI released developments and an increase in the number of student brawls for a decade, namely that fights, often called altercations, often occur among students, not even between students but also on campuses. Some say that fights between students are normal (tempo.co.id "Jakarta School Fights Up 44 percent,).

The decline in character has become a familiar sight seen in children's daily lives in the current era. Especially in the digital age, it is a challenge for parents to educate their children, so parents must be good at taking advantage of technological developments (Zubaidi et al., 2021). In the past, information was very closed and could be accessed by the desired group, but nowadays, information comes without censorship, even for young children. early can consume it (Hamzah et al., 2021). So not infrequently, if there are various deviations in children's character in the current era.

Besides that, parents and teachers' spotlight is the children's habits that often occur in the school environment, such as lying to their parents, bullying their classmates, saying rude or dirty words, and discipline in carrying out worship services only when they are at school (Munif et al., 2021). Religious teachings pay more attention to this.

Early childhood is children aged 0-6 years with rapid growth and development (Baharun, Zamroni, et al., 2021). Experts call it the golden age (Maulidiya, 2022). Early childhood is busy with imagination throughout the day, presenting their world with images, words, pictures, and magical and egocentric beliefs dominate their cognitive world (Puspitarani \& Mujab Masykur, 2018). Children are the next generation of family and nation. As the next generation, every child needs to get a good education so that his potential can develop rapidly, grow into a human being who has a rugged personality and has various abilities and valuable skills (Umiarso et al., 2022). Several studies have proven that character 
education in early childhood can be carried out with multiple methods and approaches. Teachers also internalize character education in religious education, which can be brought closer through worship activities and establishing good social relationships with others.

Learning can be achieved through methods and models in significant learning (Bali, 2020). Therefore, early childhood education must be carried out in the best way, so that good character values are embedded in the child's personality (Baharun \& Maryam, 2019). There are two objectives of implementing the PAUD program. Namely, the main goal is to form quality Indonesian children, who grow and develop according to their level of development so that they have optimal readiness to enter primary education and reduce life in adulthood (Pardosi et al., 2019).

Islamic character education not only teaches about right and wrong (Almuhajir, 2021). But it also impacts the nation's successors who continue to grow (Baharun, 2017). There are many opportunities to create a successor with nature with so many people with Islamic characters. The character or morals of Islam can be said to be Islamic morals, namely morals rooted in Allah's teachings and His Messenger (Jannah, 2021).

Character is a series of innate heart, soul, character, nature, actions, and character (Zulfaizah, 2018; Arif \& Pratama, 2019). Therefore, character education requires a process of internalizing values (Hasanah, 2021). It takes self-accustoming that goes into the heart to grow from within, which is related to the internalization of religious importance (Atika et al., 2021). The internalization of religious values occurs through a critical understanding and appreciation of spiritual teachings. It is then continued with an awareness of the importance of religious doctrines or teachings and can realize them in real life (Bali \& Fadilah, 2019).

Not all schools, especially Kindergartens in the Sukodadi area, have a comprehensive character education program. The symptoms of the problem of declining children's morale are increasingly worrying. Therefore, schools must have programs to develop character comprehensively. The Masyithoh Kindergarten institution wants to form more perfect morals that recede with the times. By bringing students to introduce the Koran by memorizing it. The entire teacher council deliberated to add activities to learn the Quran/Tahfidz Quran as the formation of Islamic character in early childhood as a successor for developing the country's future.

The Masyithoh Kindergarten School included a competition event for some students already equipped with Islamic education in their family environment before finally forming the tahfidz Qur'an program at the institution. And after seeing the results of the race. The principal is increasingly convinced to hold a tahfidz Qur'an program at the institution, which in the institution has previously had several teachers who are equipped with hafidzah. And the decision was made to form a tahfidz program in the institution. For the past three years, the tahfidz program has continued to grow.

Developing Islamic character in children, from religious and moral values, learning the tahfiz Quran is an integral part of early childhood learning. Learning Tahfiz Al-Qur'an teaches children to know the holy book of Islam from an early age. In addition, learning Tahfiz Qur'an can familiarize children with worship by preserving the Qur'an.

The Qur'an also has many advantages, including the Qur'an is a book that is easy to memorize and understand. This is by the Word of God in the Qur'an Surah al-Qamar (54:13):

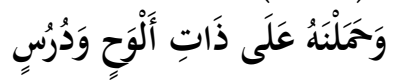

"And indeed, We have made the Qur' an easy for learning, so is there anyone who takes lessons? (Yusron Masduki, 2018).

From the above verse, it has been said; the Qur'an is easy to learn. This includes understanding and memorizing it. Each strand of the poem is easy to remember and understand.

A proverb reminds us that learning when you are small is like painting on a rock, and learning when you are big is like painting on water (Rifa'i, 2018). Early childhood has a strong memory of what they encounter with their senses so that any information they receive will be 
easy to remember and put into practice (Maskur, 2018). A teacher with good character is an effort made by a teacher to direct and educate students well (Muali \& Qodratillah, 2018). Wasilah, the teacher's prayer and the peace of mind possessed can bring the nation's successors to develop, especially in character education at the next school level, even to grow up.

Tahfidz Al-Quran, or memorizing the Quran, is noble and commendable. Because people who remember the Quran are servants of the Ahlullah on earth, it is not easy to memorize the Quran; unique methods are needed when learning it (Suryana et al., 2019). During the process of memorizing the Quran, there are 3 (three) activities that can be done at once: reading, repeating the task, and storing the remembered reading in memory.

A proverb reminds us that learning when you are small is like painting on a rock, and learning when you are big is like painting on water (Rifa'i, 2018). Early childhood has a strong memory of what they encounter with their senses so that any information they receive will be easy to remember and put into practice (Maskur, 2018). A teacher with good character is an effort made by a teacher to direct and educate students well (Muali \& Qodratillah, 2018). Wasilah, the teacher's prayer and the peace of mind possessed can bring the nation's successors to develop, especially in character education at the next school level, even to grow up.

This research is about the implementation of the Tahfidz Al Qur'an program in developing Islamic Character in Masyitoh Paiton Kindergarten Probolinggo based on Researcher Exploration. There are several research results that have relevance to this research, including: 1. Ahamd Paridi, title: Learning Tahfidz Al Qur'an in Cultivating Islamic Character in Islamic Elementary School Nurul Qur'an Semarang. 2. Ummi Kulsum with the title: Implementation of Hifzil Qur'an Learning in Forming the Religious Character of Students at MTs NU Miftahul Huda III Dawe Kudus. 3. Rochmatun Nafi'ah, Research Title: The Effectiveness of the Tahfidz Al Qur'an Program in Strengthening the Character of Students at Madrasah Aliyah Negeri Lasem.

The research conducted by researchers has its own uniqueness, namely the tahfidz qur'an program for early childhood, and the tahfidz program is a high commitment and the result of integration of the vision and mission of Masyitoh Kindergarten itself.

Based on this description, the implementation of the tahfidz program in developing Islamic character in schools can be done through several things, including habituation activities that are carried out regularly, a fun learning process, exemplary teachers, and through guidance given to students.

\section{METODOLOGY}

This study uses a qualitative approach to the type of phenomenology. This approach is the right way to express and interpret various interrelated and influential activities. The research subjects were chosen because of their expertise or ability and involvement with the Tahfidz Qur'an program in developing Islamic character in Masyithoh Kindergarten (TK). research subjects and informants who will be used as sources of data mining by researchers with the focus of research are students, Ustadzah Tahfidz and the principal of the Masyithoh Kindergarten.

In the process of collecting research data, three main methods are used simultaneously, namely interviews, observation, and documentation. Interview is a data collection technique used by researchers to obtain oral information through conversing and face to face with people who can provide information. about the implementation of the Tahfidz Qur'an program in developing Islamic character in Masyithoh Kindergarten (TK) for researchers. The data analysis technique in this phenomenographic research is a constant comparative analysis technique (Constant Comparative Analysis). In this study, the researcher compares events that can be applied to each category, combines the types and their characteristics, limits the scope of the theory, and ends by writing a thesis (Thai et al., 2012).

There are three processes in Constant Comparative Analysis: open coding, axial coding, and selective coding (Thai et al., 2012). Open coding is used to identify the main 
categories of data content. The second process is axial coding, namely identifying the specific properties of the dimensional types that are reconstructed from the data separated from the open coding. The third process is selective coding to find the main point to answer questions study. The research process is described as figure 1.

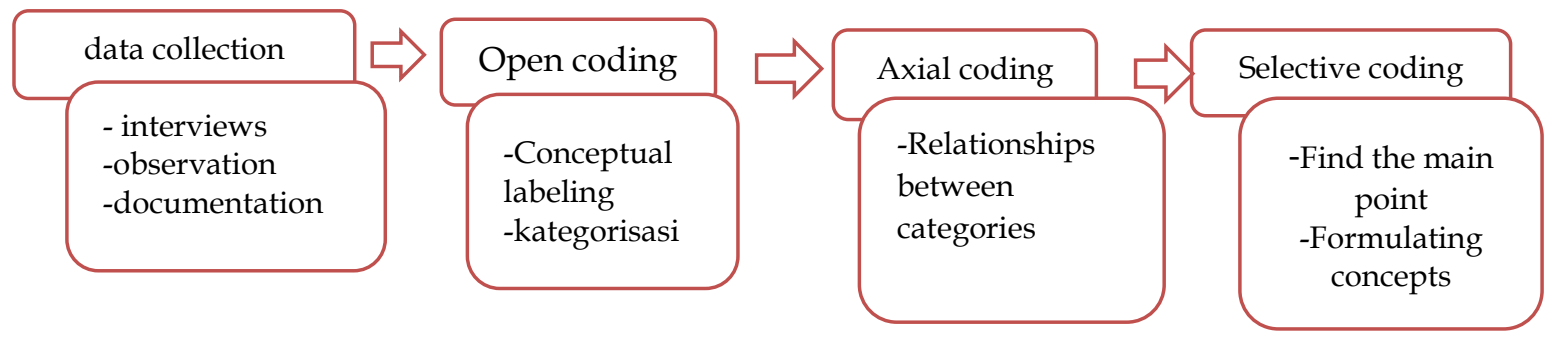

Figure 1. Research Design

Open Coding Researchers conducted an open coding process from the data obtained and identified three categories related to implementing the tahfidz Quran program in Masyithoh Kindergarten in developing children's character. Figure 2 shows the categories and sub-categories obtained from the open coding. Based on axial coding, the researchers focused on three categories related to the implications of the Tahfidz Quran program in developing Islamic character, namely the preparation stage, planning stage, and implementation stage. Selective coding is finding the main point to answer the research question. Research findings that have been categorized are linked to finding a significant category.

\section{RESULTS AND DISCUSSION}

Memorizing the Quran can form an Islamic character for Hafid's personal and an example for the community. Al-Quran is a universal guide for humans. The more you read, memorize, and understand, the greater the guidance from Allah will be obtained. The goal is the creation of ideal human beings who can realize their various potentials optimally so that they are religious, patient, persistent, and disciplined. On the other hand, if a person does not have good morals, he will become a useless person and even harm others. The danger that most humans have suffered today is called split personality (multiple personalities), where the words and actions are different (Fattah Hidayat,2017).

The school has a learning program that some children follow in Masyithoh Kindergarten. One of the objectives of this learning can be used as a method or means to develop Islamic character in children. The teaching in question is learning the Tahfidz Quran. Here are some research processes on developing Islamic character through the Tahfidz Quran program.

Based on the results of interviews, observations, and document studies of informants and data sources at Masyitoh Kindergarten Probolinggo, the researchers describe the research findings as follows: :

\section{Implementation \\ Planning the tahfidz quran program in developing Islamic character}

To implement the tahfidz quran program in Masyithoh Kindergarten, there is a strong desire to develop rapidly. So that the development of tahfidz Quran in Masyithoh Kindergarten has a vision, namely "Forming a Generation of Qur'ans who are Sholeh, Skilled and Have Noble Morals". To achieve this achievement, Ustadzah explained the mission he was carrying out, namely: First, carry out learning in a professional, comprehensive and balanced manner; second, carry out learning that is able to provide knowledge of independent attitudes, noble character, skill; third, building Islamic character in students (TK. Masyitoh Documentation) 
According to Quraish Shihab, Hafiz is taken from three letters that have the meaning of maintaining and supervising (Hidayah, 2016). A memorizer is a person who holds memorization in his memory, heart, and wherever the memorizer is. All of this happens because the mind in the subconscious has fused with the verses of the Koran. Supervising means supervising so that the memorization is not lost and the memorization becomes more mutqin and reduces forgetfulness. The memorizer will quickly move on to the next sheet or surah because the previous memorization has been attached well.

The school organizes the tahfidz quran program for the development of Islamic character in early childhood, namely with the union of parents and guardians of students, TPQ Al-muhajjirin. The form of this collaboration is the implementation of the tahfidz quran learning program, coaching tahfidz teachers, coaching children in the process of memorizing the Koran (interview with Alfiyah, S. Pd Head of Masyitoh Kindergarten).

Memorizing the Qur'an is an activity that is filled with efforts that require the memorizer always to be consistent (Fajarin et al., 2017). Memorizing the Qur'an is not merely learning by relying on the power of memory but includes a series of processes that must be followed by memorizing the Qur'an after being able to remember the Qur'an in quantity (Adiwijayanti et al., 2019).

The participation of outside parties in tahfidz quran activities in schools is a form of preparation for the tahfidz quran program at Masyithoh Kindergarten. The WhatsApp group of guardians of students makes intense communication between ustadahz and parents a reality. In addition, books have been provided to control the time in the process of repeating memorization (murojaah). ) at home (interview with Alfiyah, S. Pd Principal of Masyitoh Kindergarten).

Direct interaction with teachers is more effective in learning. The functions of character education areas; development, improvement, and screening. The development process is to develop students' potential into good behavior, especially for students who have reflected the nation's character. The function of improvement is to strengthen the role of national education, namely as the person in charge of the potential of more dignified students. The filter filters out the culture of one's nation and the culture of other countries that are not by the values of a noble character(Chusnul Muali, 2019).

\section{The category of preparation for the tahfidz Quran program in developing Islamic character}

All informants said there was no special preparation to realize the tahfidz Quran program at Masyithoh Kindergarten. The three informants had never attended special training on implementing the tahfidz Quran program, but some teachers considered the tahfidz Quran program to develop Islamic character in Masyithoh Kindergarten. Hence knowledge. The informant said that there was a tahfidz Quran program at Masyithoh Kindergarten: 1) with the tahfidz program, children would be trained to read the Koran well, 2) the tahfidz Quran program educates children to be disciplined when reading the Koran, 3) the tahfidz Quran program creates a sound generation in developing Islamic character of children (interview with juwariyah ulfa masyithoh kindergarden tahfidz teacher)

The informant said there was no special preparation for implementing the tahfidz Quran program at Masyitoh Kindergarten. The Tahfidz Quran program is integrated with existing school programs. The school does not explicitly map students but accepts children interested in the Tahfidz Quran program. Recommend to parents how to program the tahfidz Quran in schools. Informants stated that they did not implement an inclusive school curriculum. The Tahfidz Quran program is guided directly by an ustadzah who has finished memorizing 30 juz (tahfidz). and by application in collaboration with TPQ al-Muhajirin ((interview with Alfiyah, S. Pd Head of Masyitoh Kindergarten).

The principal does not make specific policies regarding the tahfidz quran program, but some educational programs are directed to the tahfidz quran program. The planning of the tahfidz quran program has not been specifically included in the school budget plan, but is 
integrated into routine school activities. The results of this study indicate that TK. Masyitoh has a high commitment to forming an Islamic character with the Tahfidz Quran program.

\section{Category of the implementation of the tahfidz Quran program in developing Islamic character}

To implement the tahfidz quran program in Masyithoh Kindergarten, there is a strong desire to develop rapidly. So that the development of tahfidz Quran in Masyithoh Kindergarten has a vision, namely "Forming a Generation of Qur'ans who are Sholeh, Skilled and Have Noble Morals". To achieve this achievement, Ustadzah explained the mission he was carrying out, namely: first, carry out learning in a professional, comprehensive and balanced manner; second, carry out learning that is able to provide knowledge of independent attitudes, noble character, skill; Third, building Islamic character in students

Departing from the school's vision and mission and a high commitment in developing the Islamic character of early childhood in Masyitoh Kindergarten, the Tahfidz Qur'an program was implemented as an effort to form Islamic character in students. At the stage of implementing the tahfidz qur'an program in shaping Islamic character using a method that can help memorizers when memorizing the Qur'an is the wahdah method. The Wahdah method is memorizing one verse in the Koran 10 times to 20 times so that it forms a pattern in the shadows, meaning imagining the letters to be memorized. As for the steps in achieving initial memorization (interview with Ulin Baenana Guru Hafidz TK Masyitoh); First, ustadz read verses or letters repeatedly in front of children who want to memorize. 10 to 20 times; second, then after being repeated, the child repeats the surah or verse read by the cleric; third, ustadzah listens and assesses how fluently the child reads tajwid and makhroj; fourth, provide an understanding of the letter that is being memorized by the child, so that the child can understand the meaning of the memorized verse. And a shadow appears as explained by the cleric about the content of the verse; fifth, ustadah will continue to repeat for children who are not yet fluent in reading and monitoring tadarus books at home (figure 2). With the aim that children at home continue to recite and murojaah (repeat); sixth, after finishing adding letters, the ustadzah evaluates the previous memorization by launching the previous memorization.

Tahfidz Al-Qur'an learning has been carried out since 2018 every morning before entering the first lesson hours, which is $08.00-08.30$ WIB from Saturday to Friday. Tahfidz learning is carried out routinely 6 days each week, and is in the form of individual face-to-face activities between teachers and students. (researcher observation). The teacher can explain how to pronounce makhorijul letters or where the letters come out, then give examples of the sounds of the letters so that students can immediately imitate the letters or verses of the Koran that are read. Reading the verses can be done repeatedly until the memorization is stored in the child's memory. Reading the Koran in front of the teacher is an important element in the tahfidz al-Quran learning system, on the other hand it can maintain the power of memorizing the Koran (interview with Juwairiyah Ulfa, a kindergarten teacher. Masyitoh).
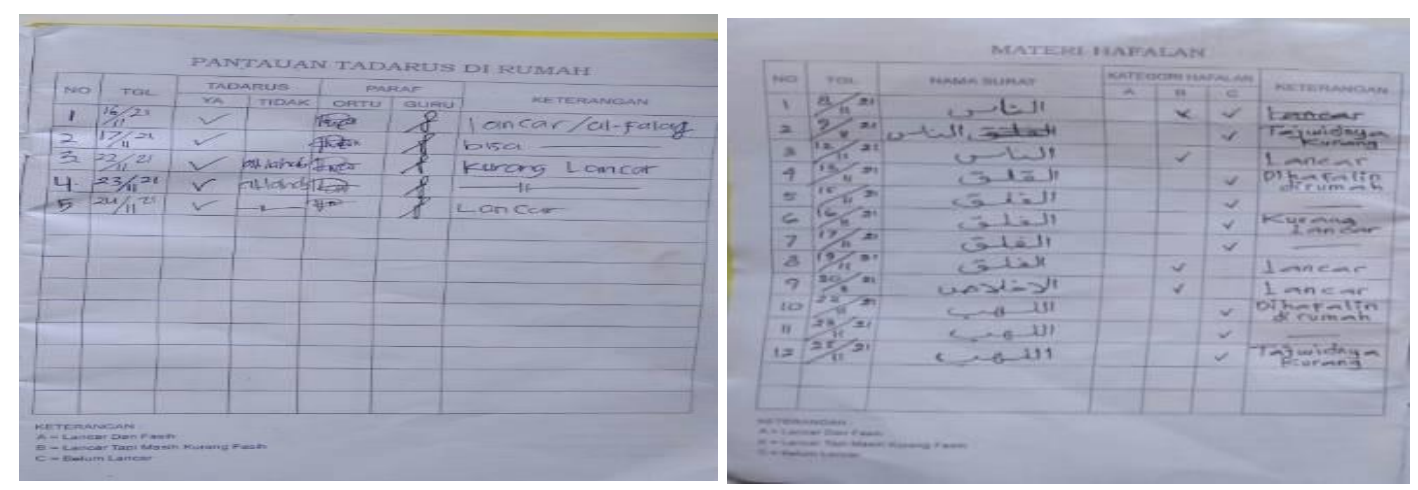

Figure 2. Tadarus monitoring book at home Memorizing material book Source: researcher documentation 
As for the advantages of the wahdah method itself, this method can make it easier for children to recognize letters, pronounce letters, read Arabic sentences and words, read verses of the Koran properly and correctly (figure 3). This method is also easier for Hafid to do, the child's memory of the memorization that has been done is stronger, and the child's makharijul letters in reciting the Koran are guaranteed. Children's persistence in adding memorization is also more consistent. In addition, recitation and some rules of reading the Koran with tartil are maintained. However, there are some things that sometimes hinder students in memorizing. (interview with Ulin Baenana Guru Hafidz TK Masyitoh)

With the wahdah method, the child feels very long in memorizing because he has to repeat it many times until he really memorizes it before finally moving on to the next letter or verse. Especially for early childhood, it will take a lot of time to apply the wahdah method. Because they have to adjust their time when playing and when memorizing.

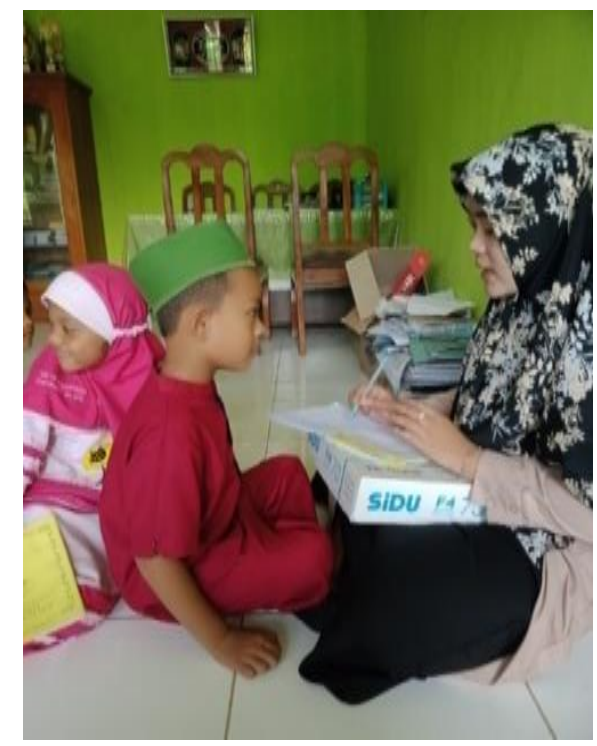

Figure 3. The teacher reads and the child pays attention to the pronunciation of the letters Source: researcher documentation

Besides doing Qur'an memorization learning with the Wahdah method optimally in order to accelerate students' Qur'an memorization, there are also structured activities and IslamicQur'anic habituation in developing Islamic character through: memorizing daily prayers, the culture of reading short letters of the Koran before starting the lesson, the culture of praying Dhuha congregation, Murojaah, Tadarus, and the culture of cleanliness (Interview with Alfiyah, S. Pd Principal of Masyitoh Kindergarten).

\section{Category evaluation program Tahfidz Quran}

Evaluation of Tahfidz Quran learning in Masyithoh Kindergarten is carried out to develop Islamic character. teachers can integrate the optimization of these characters in the educational process. The concrete form is in the form of periodic tests by the tahfidz teacher, the ustadzah checks and tests all students who have memorized the Qur'an, this test is carried out every time there is a tahfizh Qur'an subject or once a week according to their abilities and in accordance with the limits. each class by being given a star or gift by the ustadzah, with the aim of uplifting and increasing their motivation in maintaining their own memorization (Interview with alfiyah, S. Pd Principal of TK Masyitoh).

Provide opportunities for tahfidz children to lead the reading of short letters in the prophet's birthday, muharroh, and separation events. And the evaluation that culminates is when students are about to graduate from Tahfizh Qur'an, the ones who test it are their respective parents on stage (Teacher Hafidz TK Masyitoh). 
As for evaluating the Islamic character applied in kindergarten. Masyitoh is to use the Guidance Book, this book contains messages conveyed by ustadzah to parents of students in order to evaluate the cognitive, affective, and psychomotor of students. This book is also a report on the formation of student character while in school (Documentation of TK Masyitoh).

In the form of an external evaluation, the school routinely sends students to participate in local and long-distance MTQ and MHQ competitions. Some students were able to win the competition to read and memorize short letters (interview with Ulin Baenana Guru Hafidz TK Masyitoh). Evaluation of tahfidz Quran children in various activities can seen on figure 4.

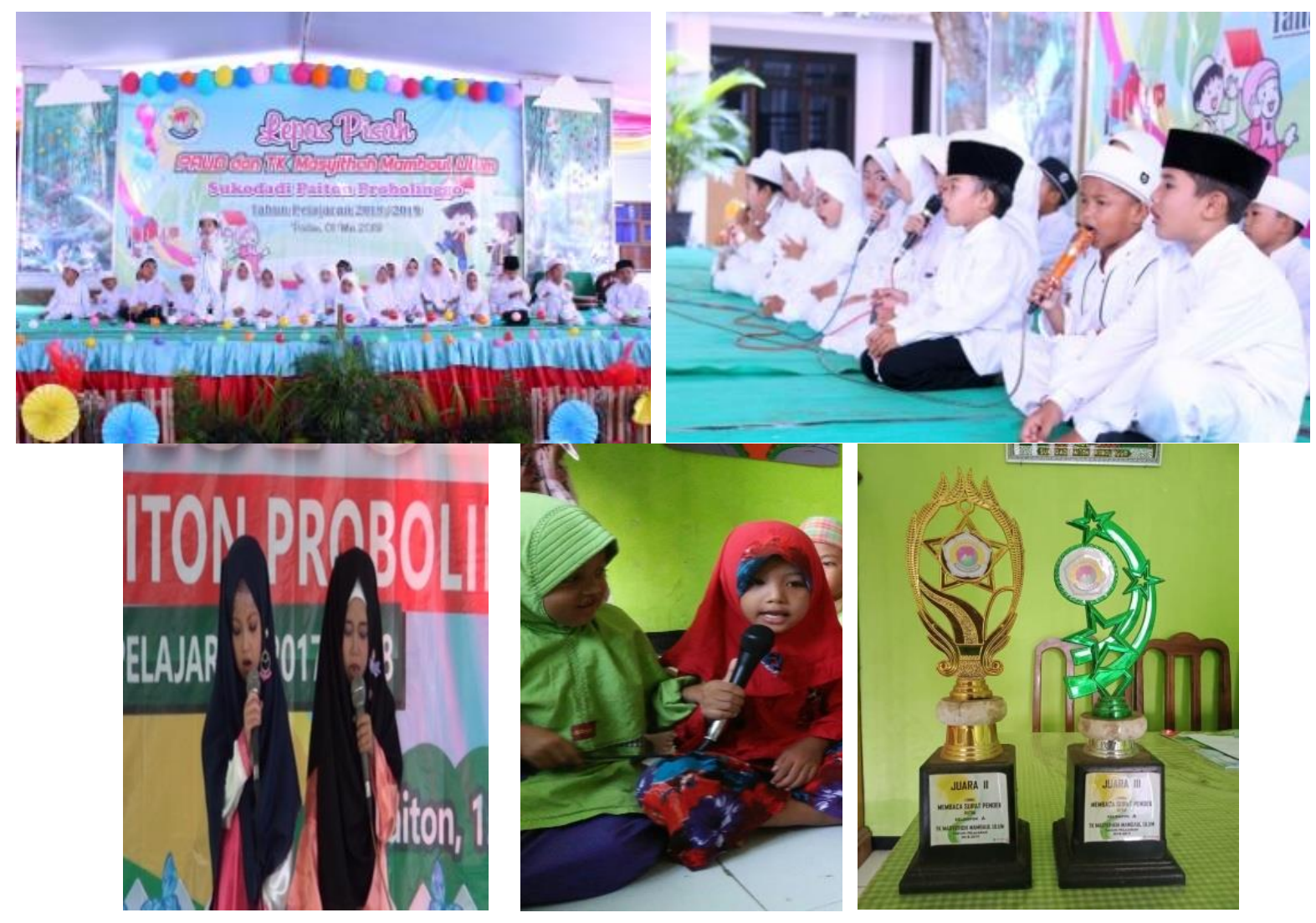

Figure 4. Evaluation of tahfidz Quran children in various activities

Source: researcher documentation

The implementation of learning activities is an effort made by educators to realize the designs that have been prepared well. Therefore, the implementation of learning activities that show the application of methods and strategies for teaching and learning activities In general, there are several steps taken by educators and students in implementing Tahfidz Al-Qur'an learning including:

Steps for Tahfidz Al-Qur'an Learning, Principals and Ustadah implement the school's vision and mission which is rich in Islamic-Qur'anic values, and collaborate with the Al-Qur'an Tahfidz Team (TPQ) almuhajirin, the school prepares all facilities and infrastructure to support the process of developing Islamic character education in Tahfidz Al-Qur'an learning, schools supervise the process of developing Islamic character in Tahfidz Al-Qur'an learning through structured programs. The school evaluates the implementation of planting Islamic character education in learning Tahfidz Al Qur'an on a regular and systematic basis.

Tahfidz Al-Qur'an learning has been carried out since 2018 every morning before entering the first lesson hours, which is $08.00-08.30$ WIB from Saturday to Friday. In memorizing the Qur'an (juz 'amma or juz 30), the method used is the wahdah method, this method can make it easier for children to recognize letters, pronounce letters, read Arabic sentences and words, read verses of the Koran properly and correctly. . This method is also easier for Hafid to do, the child's memory of the memorization that has been done is stronger, 
and the child's makharijul letters in reciting the Koran are guaranteed. Children's persistence in adding memorization is also more consistent. In addition, recitation and some rules of reading the Koran with tartil are maintained. The choice of this strategy is due to the differences in the abilities of each student. There are students who are fluent in reading the Qur'an, some are not fluent in reading the Qur'an. So that students who are not fluent in reading the Qur'an can follow or compensate for those who are already fluent in reading the Qur'an, all students read verse by verse together.

At the time of the implementation of memorization, of course the condition of students varies greatly. There are students who are enthusiastic about participating in the memorization process from beginning to end, some are talking to their friends, some are not memorizing and imitating their friends hesitantly, some are pranking their friends. The various behaviors that arise from these students can still be overcome by the seriousness of the teacher in carrying out their duties and responsibilities. For example, with full supervision and assistance, walking around students, and reminding students who are noisy. To find out and ensure students' memorization, the teacher conducts an assessment in each semester by asking students to advance one by one. In addition, sometimes teachers also occasionally test students' memorization after the memorization process takes place.

Tahfidz Al-Quran, or memorizing the Quran, is noble and commendable. Because people who remember the Quran are servants of the Ahlullah on earth, it is not easy to memorize the Quran; unique methods are needed when learning it (Suryana et al., 2019). During the process of memorizing the Quran, there are 3 (three) activities that can be done at once: reading, repeating the task, and storing the remembered reading in memory.

Islamic character formation is a planned and systematic effort to make someone recognize, care about and internalize Islamic values to behave as a human being. Character formation is carried out in an integrated and internalized way through every learning material and activity involving early childhood directly (Wahyuningtiyas \& Ansori, 2017). Internalization of morality and morality in learning can print optimal learning outcomes and generate tafaqquh finding (Faizatul Widad, 2019).

\section{Implications of the Tahfidz Qur'an Program in shaping Islamic Character in Masyitoh Kindergarten}

The implication of learning tahfidz quran is to apply inclusive learning, social education, Islamic character-based education. Implementation of the character of students in learning tahfidz Al Qur'an at Masyithoh Kindergarten, Kab. Probolinggo is reflected in his attitude achievements (Interview with Alfiyah, S. Pd Head of TK Masyitoh): First, Religious. What is meant by religious is that students are closer to God, such as praying fervently so that students can read the Koran more quickly and memorize the Koran according to the target. Plus the habit of students praying before and after learning, getting used to learning ablution 'and praying every Friday. Second, Istiqamah. What is meant by istiqamah is that students who learn tahfidz must remain steadfast in learning under any conditions and anywhere because learning to read and memorize the Qur'an is a job that is not light and requires sacrifice, the persistence of students in depositing memorization. Third, Discipline. What is meant by discipline must be disciplined to repeat the lesson. Discipline depositing the memorization according to the schedule set. Fouth, Be patient. It means being patient in dealing with verses that are sometimes very difficult to remember. Patience is the key to success in achieving goals, including the goal of memorizing the Quran. Because basically someone who memorizes the Qur'an will have difficulties and obstacles if it is not accompanied by patience. Patience is needed because memorizing the Quran requires a relatively long time and full concentration.

The implementation of the tahfidz Qur'an program in developing Islamic character at Masyitoh Paiton Kindergarten Probolinggo has been going well, to develop Islamic characters (Religious, Disciplined, Patient, and Istiqomah) in various ways ranging from the learning 
process, example, habituation, environmental formation in the community. school. Islamic characters are also applied to: Performing ablution before studying Tahfidz Al Qur'an, praying before and after learning Tahfidz Al Qur'an, praying after each study, special prayers to parents and other prayers. Clean character is applied to: outwardly clean (ablution before studying, clean clothes, clean study area and the tools used in learning must be clean. Disciplined character is applied to: the discipline of praying before and after studying, the discipline of arriving at the study place on time, discipline repeating the memorization, and the discipline of depositing the memorization. The character of istiqamah is applied to: the persistence of students in memorizing and the persistence of students in depositing the memorization. The character of patience is applied to: the patience of students in repeating the memorization, the patience of students in the students in depositing the memorization, the patience of students in learning and the patience of students in replay.

The research findings on Islamic character in Masyitoh Kindergarten align with the existing theory as a character is built based on three components, namely knowledge, attitude, and behavior. These three components cannot be separated because each has an attachment. Character education is done by example or treatment, not just a theory (Ahmad Tafsir, 2011). For this reason, every parent of students and educators at Masyitoh Kindergarten must always strive to instill a positive character in each child as a form of contribution and role model both verbally, attitude and practice.

According to Amirullah Syarbini, the character is a stable, particular trait inherent in a person's personality that makes him act and act spontaneously, not influenced by conditions and without needing it first. Character education is an effort to cultivate intelligence in thinking, appreciation in the form of attitudes, and experience in the form of behavior that is by the noble values that become identity which is manifested in the form of interaction with God, oneself, society, and the environment (Zubaedi, 2011).

The Journal of Moral Educational volume 36 of 2007 specifically explained spirituality and religious values that cannot be separated from character education. In Islamic teachings, all aspects of disciplines and the order of life are always related to character (Abdul Madjid dan Dian Andayani, 2011). The importance of character instilled from an early age is a learning process that can make it easier for children to be commendable and interact well. In addition, parents' primary obligation is to provide happiness and welfare for their children so that they grow and live happily so that the children can be independent and contribute to the interests of the people in the future.

In addition to giving orders to treat children well, the Qur'an has also set an example for parents in educating their children, as exemplified by Luqmanul Hakim. The name Luqmanul Hakim is enshrined in the Qur'an as a figure in educating children because of the learning process and methods given in the way of wisdom. According to Quraish Shihab, Wisdom is everything, if used or considered, will bring greater or greater benefit and convenience and prevent major or more significant harm or difficulty (Quraish M. Shihab, 2002).

The formation of Islamic character is manifested in the example of the Prophet Muhammad SAW through four characters. First, Sidiq means right in speaking, acting, and behaving. The two mandates are trustworthy both in speech and behavior, the third Tabligh means accountable or conveys well and professionally, the fourth Fathonah means intelligent, what is meant here is intelligent not only intellectually brilliant but able to control emotions and make himself a problem solver in personal issues and various issues of the people. In addition, the Prophet was able to go through multiple life problems with complete patience, calm, and sincerity. The Prophet's resilience in dealing with situations and conditions is the starting point for a leader who can overcome obstacles by solving problems wisely and making opponents friends. This attitude is a character education that is well developed and accustomed to controlling various barriers and difficulties related to social conditions. In 
addition, the nature of empathy built in the Prophet made every opponent from different circles make the Prophet an example throughout the ages.

Based on the Qur'an and hadith, the Islamic character formed in Masyitoh Kindergarten with Program Tahfidz, so that it can deliver intellectually intelligent children, emotionally wise and spiritually pious so that it can deliver not only righteous individually but can create socially holy and make the country happy and blessed by Allah SWT. Based on the Qur'an and hadith, the Islamic character formed in Masyitoh Kindergarten with Profram Tahfidz, so that it can deliver intellectually intelligent children, emotionally intelligent and spiritually pious, so that it can deliver not only pious individually but can create socially pious and make the country happy and blessed by Allah SWT.

\section{CONCLUSION}

The implementation of the Tahfidz Qur'an program in developing Islamic character in Masyithoh Kindergarten is planning, preparation, implementation and evaluation of the program. The implementation of tahfidz quran education uses the wahdah method, tahfidz quran with the wahdah method is memorizing the Quran by memorizing one verse by one to memorize. By listening to the tashih makhraj, tashih letters, and tashih tajwid. In addition, there are structured activities and Islamic-Qur'anic habituation in developing Islamic character through: memorizing daily prayers, the culture of reading short letters of the Koran before starting lessons, the culture of praying Dhuha congregation, Murojaah, Tadarus, and hygiene culture

\section{ACKNOWLEDGMENT}

Motivation from various parties. Therefore, I would like to express my deepest gratitude with the words of jazakumu allah ahsana al jaza' to: Rector of Nurul Jadid University Paiton Probolinggo, Rector of Universitas Islam Negeri Sultan Aji Muhammad Idris, Samarinda, Dean of Nurul Jadid University Paiton Probolinggo and Head of PIAUD University Nurul Jadid University Paiton Probolinggo. Head, Educator, Masyitoh Probolinggo Kindergarten Education Personnel

\section{REFERENCES}

Adiwijayanti, D. D., Purwati, H., \& Sugiyanti, S. (2019). Pengaruh Hafalan Al-Qur'an Terhadap Prestasi Belajar Matematika Siswa MTs. Square : Journal of Mathematics and Mathematics Education, 1(2), 109. https:/ / doi.org/10.21580/square.2019.1.2.4771

Almuhajir, A. (2021). Controlling the Muhammadiyah Lhokseumawe Orphanage in Forming Independent Character of Foster Children. Al-Tanzim: Jurnal Manajemen Pendidikan Islam, 5(1), 176-189. https:// doi.org/10.33650/al-tanzim.v5i1.1962

Arif, D., \& Pratama, N. (2019). Tantangan Karakter di Era Revolusi Industri dalam Membentuk Kepribadian Muslim. Al-Tanzim: Jurnal Manajemen Pendidikan Islam, 03(01), 198-226. https:// doi.org/10.33650/al-tanzim.v3i1.518

Arliman S, L. (2018). Peran Komisi Pelindungan Anak Indonesia Untuk Mewujudkan Perlindungan Anak Di Indonesia. Jurnal Hukum Respublica, 17(2), 193-214. https://doi.org/10.31849/respublica.v17i2.1932

Atika, A., Arifin, Z., \& Jannana, N. S. (2021). Integrated School Management-Character Education Affirmation: A Case Study in Muhammadiyah Wirobrajan 3 Elementary. AL-TANZIM: Jurnal Manajemen Pendidikan Islam, 5(2), 15-26. https://doi.org/10.33650/al-tanzim.v5i2.1970

Baharun, H. (2017). Total Moral Quality: A New Approach for Character Education in Pesantren. Ulumuna, 21(1), 57-80. https:/ / doi.org/10.20414/ujis.v21i1.1167 
Baharun, H., \& Badriyah, N. (2021). Representasi Nilai-Nilai Karakter Sebagai Role Model d alam Film " Arbain " (Sebuah Analisis Semiotik). TADRIS: Jurnal Pendidikan Islam, 16(2), 436-452. https:/ / doi.org/10.19105/tjpi.v16i2.4842

Baharun, H., \& Maryam, S. (2019). Building Character Education Using Three Matra of Hasan Al-Banna's Perspective in Pesantren. Jurnal Pendidikan Islam, 4(2), 51-62. https://doi.org/10.15575/jpi.v4i2.2422

Baharun, H., \& Zulfaizah. (2018). Revitalisasi pendidikan agama dalam pembentukan karakter peserta didik di madrasah. Elementary, 6(1), 43-62.

Baharun, H., Muali, C., Bali, M. M. E. I., Rozi, F., Rodiah, L. N., Munawaroh, Z., \& Aminah, S. (2021). Learning Strategies for Mobile-Assisted Seamless Learning: A Students' Initial Perceptions. Proceedings of the First International Conference on Science, Technology, Engineering and Industrial Revolution (ICSTEIR 2020), 536(Icsteir 2020), 557-560. https:// doi.org/10.2991/assehr.k.210312.089

Baharun, H., Zamroni, A., \& Saleha, L. (2021). Pengelolaan APE Berbahan Limbah untuk Meningkatkan Kecerdasan Kognitif Anak. Jurnal Pendidikan Anak Usia Dini, 5(2), 1382-1395. https:// doi.org/10.31004/obsesi.v5i2.763

Bali, M. M. E. I. (2020). Penerapan Model Pembelajaran Two Stay Two Stray dalam Meningkatkan Keaktifan Belajar Pebelajar. Muróbbî: Jurnal Ilmu Pendidikan, 4(1), 2942. https://doi.org/10.52431/murobbi.v4i1.225

Bali, M. M. E. I., \& Fadilah, N. (2019). Internalisasi Karakter Religius di Sekolah Menengah Pertama Nurul Jadid. Jurnal MUDARRISUNA: Media Kajian Pendidikan Agama Islam, 9(1), 1-25. https:// doi.org/10.22373/jm.v9i1.4125

Dakir, El Iq Bali, M. M., Zulfajri, Muali, C., Baharun, H., Ferdianto, D., \& Al-Farisi, M. S. (2021). Design Seamless Learning Environment in Higher Education with Mobile Device. Journal of Physics: Conference Series, 1899(1), 1-5. https://doi.org/10.1088/17426596/1899/1/012175

Faizatul Widad. (2019). Telaah Nilai Nilai Pendidikan Antikorupsi Dalam Pendidikan Agama Islam Di Madrasah Ibtidaiyah. Murobbi: Jurnal Ilmu Pendidikan, 3(01), 85-101. https:// doi.org/10.32699/paramurobi.v3i2.1386

Fajarin, A., Sutoyo, A., \& Sugiharto, D. Y. P. (2017). Model Menghafal pada Penghafal AlQur'an Implikasinya pada Layanan Penguasaan Konten dalam Bimbingan dan Konseling. Jurnal Bimbingan Konseling, 6(1), 13-19.

Hamid Wahid, A., Rozi, F., Baharun, H., Musyrifah, Hidayati, W., Sriwahyuningsih, A., Ni'mah, M., \& Bon, A. T. (2021). Information technology in the development of language aspects of early childhood. Proceedings of the International Conference on Industrial Engineering and Operations Management, 6994-7000.

Hamzah, N. H., Khomaeny, E. F. F., \& Ulfa, M. (2021). Tontonan anak di Televisi: Paradoks dan Kontestasi Nilai Tontonan Anak di Media Televisi Nasional. Jurnal Obsesi : Jurnal Pendidikan Anak Usia Dini, 5(2), 1883-1893. https:/ / doi.org/10.31004/obsesi.v5i2.713

Hasanah, U. (2021). Nilai-Nilai Pendidikan Karakter; Penguatan Berbasis Kegiatan Ekstrakurikuler Pramuka di Pesantren. Manazhim : Manajemen Dan Ilmu Pendidikan, 3(1), 110-126. https:// doi.org/10.36088/manazhim.v3i1.1075

Hermawan, D. I. (2020). Dampak Sinetron Romantis Terhadap Perilaku Anak Sekolah Dasar. EduPsyCouns : Journal of Education, Psychology and Counseling, 2(1), 13-21.

Hidayah, N. (2016). Strategi Pembelajaran Tahfidz Al-Qur'an di Lembaga Pendidikan. Ta'allum: Jurnal Pendidikan Islam, 4(1), 63-81. https:// doi.org/10.21274/taalum.2016.4.1.63-81

Jannah, I. K. (2021). Revitalisasi Pemberdayaan Budaya Karakter Nuansa Religiustik dalam Membentuk Perilaku Pekerti Santri. Murobbi https:// doi.org/10.52431/murobbi.v5i1.334

Maskur, A. (2018). Pembelajaran Tahfidz Alquran pada Anak Usia Dini. IQ (Ilmu Al-Qur'an): Jurnal Pendidikan Islam, 1(02), 188-198. https:// doi.org/10.37542/iq.v1i02.15 
Maulidiya, H. (2022). The ' Sekolah Sak Ngajine ' Program; The Habit of loving the Qur ' an from an Early Age based on Tilawati. 6(3), 1667-1676. https://doi.org/10.31004/obsesi.v6i3.1636

Muali, C., \& Qodratillah, K. R. (2018). Pengembangan karakter guru dalam menghadapi demoralisasi siswa perspektif teori dramaturgi. Jurnal MUDARRISUNA: Media Kajian Pendidikan Agama Islam, 8(1), 102-126. https://jurnal.arraniry.ac.id/index.php/mudarrisuna/article/view/2792

Munif, M., Rozi, F., \& Yusrohlana, S. (2021). Strategi Guru dalam Membentuk Karakter Siswa $\begin{array}{llll}\text { melalui Nilai-nilai } \quad \text { Kejujuran. } & \text { FONDATIA, 5(2), 163-179. }\end{array}$ https://doi.org/10.36088/fondatia.v5i2.1409

Mustajab, M., Baharun, H., \& Iltiqoiyah, L. (2020). Manajemen Pembelajaran melalui Pendekatan BCCT dalam Meningkatkan Multiple intelligences Anak. Jurnal Obsesi : Jurnal Pendidikan Anak Usia Dini, 5(2), 1368-1381. https://doi.org/10.31004/obsesi.v5i2.781

Pardosi, M., Widyakanti, W., \& Ridwan, M. N. I. (2020). Implementasi Program Pendidikan Anak Usia Dini (Studi Komparatif Pada Taman Kanak-Kanak yang Terakreditasi dan Tidak Terakreditasi di Kelurahan Mantuil Kecamatan Banjarmasin Selatan). Jurnal Administrasi Publik Dan Pembangunan, 1(1). https:// doi.org/10.20527/jpp.v1i1.2483 Puspitarani, P., \& Mujab Masykur, A. (2018). Makna Menjadi Guru Taman Kanak-Kanak (Sebuah Studi Kualitatif Fenomenologis). Empati, 7(1), 308-314.

Rifa'i, A. (2018). Pendidikan Tahfiz Anak Usia Dini (TAUD). Al Qalam: Jurnal Ilmiah Keagamaan Dan Kemasyarakatan, 11(23), 113. https:/ / doi.org/10.35931/aq.v0i0.6

Suryana, Y., Dian, D., \& Nuraeni, S. (2019). Manajemen Program Tahfidz Al-Quran. Jurnal Isema : Islamic Educational Management, 3(2), 103-113. https://doi.org/10.15575/isema.v3i2.5014

Umiarso, Zamroni, \& Hidayati, N. (2022). Improving Children ' s Cognitive Intelligence Through Literacy Management. Jurnal Obsesi : Jurnal Pendidikan Anak Usia Dini, 6(3), 1588-1598. https:// doi.org/10.31004/obsesi.v6i3.1817

Wahyuningtiyas, I., \& Ansori. (2017). Upaya Pembentukan Karakter Islami Siswa Melalui Kegiatan Spiritual Camp Di Man Bondowoso. Islamic Academika, 4(1), 1-14. http:/ / ejurnal.staiattaqwa.ac.id/index.php/ojs/article/view/67

Yusron Masduki. (2018). Implikasi Psikologis Bagi Penghafal Al-Qur'an. Journal of Physical Therapy Science, 9(1), 1-11.

Zubaidi, A., Hambali, H., \& Hafita, S. N. (2021). Peran Orang Tua dalam Menyikapi Dampak Perkembangan Teknologi bagi Anak. Tafáqquh: Jurnal Penelitian Dan Kajian Keislaman, 9(2), 241-258. https://doi.org/10.52431/tafaqquh.v9i2.495 